\title{
Effect of Aqueous Extract of Launaea acanthodes on Open Skin Wound in Diabetic Rats
}

\author{
Rahbarian R. ${ }^{1}$ PhD, Sepehri Moghadam H. ${ }^{2}$ PhD, Sadoughi S.D.* PhD
}

*Young Researchers and Elite Club, Mashhad Branch, Islamic Azad University, Mashhad, Iran ${ }^{1}$ Biology Department, Sciences Faculty, Payam-e-Noor University, Tehran, Iran

${ }^{2}$ Agriculture Department, Sciences Faculty, Payam-e-Noor University, Tehran, Iran

\begin{abstract} diabetic rats. SPSS 20 software. experimental $26^{\text {th }}$ and $12^{\text {th }}$ day. accelerates the healing of diabetic ulcers.

\section{Keywords}

Wound [http://www.ncbi.nlm.nih.gov/mesh/68014947];

Diabetes Mellitus [http://www.ncbi.nlm.nih.gov/mesh/68003920];

Skin [http://www.ncbi.nlm.nih.gov/mesh/68012867];

Rats [http://www.ncbi.nlm.nih.gov/mesh/68051381]
\end{abstract}

Aims: Wound healing delay is a common complication of diabetes mellitus. Considering the antioxidant properties of the Launaea acanthodes, this study aimed to examine the effects of this plant on open skin wound healing in

Materials \& Methods: In this experimental study, 32 male rats were allocated into the equal groups of control, diabetic control and experimental diabetic 1 and 2 . The diabetes in diabetic control and experimental diabetic groups was induced using an intraperitoneal injection of alloxan. In all samples, 4 wound with $7 \mathrm{~mm}$ diameters were created in two lateral posterial parts of body. Then experimental diabetic groups 1 and 2 treated with 10 and $20 \%$ of Launaea acanthodes ointment and control and diabetic control groups treated with eucerin for 12 days. Histological studies were performed on each of the days 3 , 6, 9 and 12. Data were analyzed by Kruskal-Wallis and post-hoc Tukey tests in

Findings: The highest and lowest density of inflammatory cells in control group are $3^{\text {th }}$ and $12^{\text {th }}$ day, diabetic control $9^{\text {th }}$ and $3^{\text {th }}$ day, experimental diabetic 1 and $26^{\text {th }}$ and $12^{\text {th }}$ day. The highest and lowest thickness of the epithelium in control group are $6^{\text {th }}$ and $12^{\text {th }}$ day, diabetic control $12^{\text {th }}$ and $3^{\text {th }}$ day, experimental $19^{\text {th }}$ and $12^{\text {th }}$ day and experimental $26^{\text {th }}$ and $12^{\text {th }}$ day. The highest and lowest density of blood vessels in control group are $6^{\text {th }}$ and $12^{\text {th }}$ day, diabetic control $12^{\text {th }}$ and $3^{\text {th }}$ day, experimental $16^{\text {th }}$ and $3^{\text {th }}$ day and

Conclusion: Topical treatment of aqueous extract of Launaea acanthodes

\footnotetext{
${ }^{*}$ Corresponding Author

Tel: +985138683900

Fax: +985138683001

Address: Biology Department, Sciences Faculty, Payam-e-Noor University, Mo'allem Boulevard, Mashhad, Iran. Post Box: 91735-433

damoon.sadughi@gmail.com

Received: April 27, $2015 \quad$ Accepted: October 31, 2015 ePublished: December 15, 2015
} 
اختلالات وسيعى از جمله بيمارىهاى حسى، حركتى، عصبى، عدم

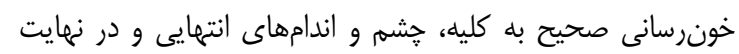

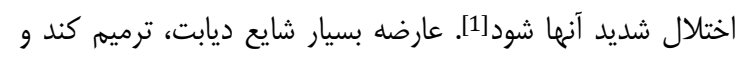

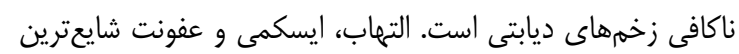

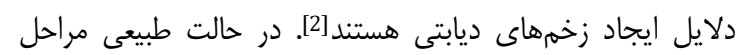

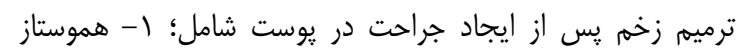

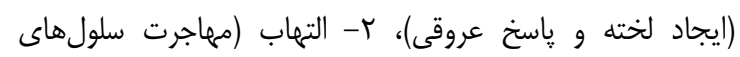

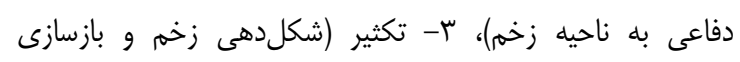

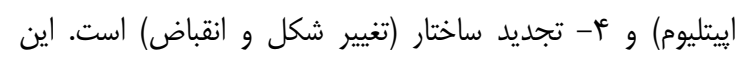

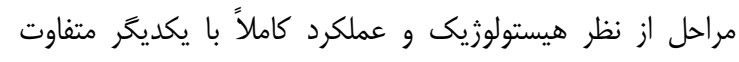

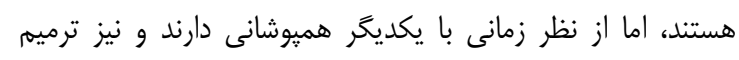

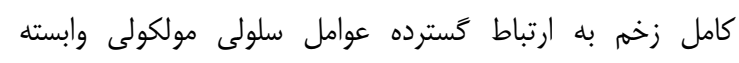

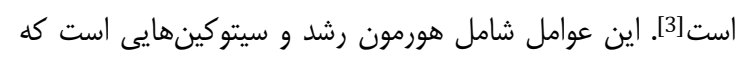

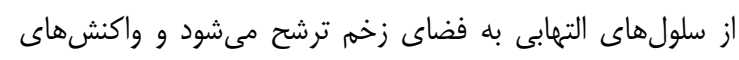

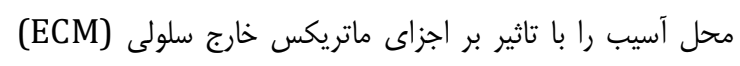

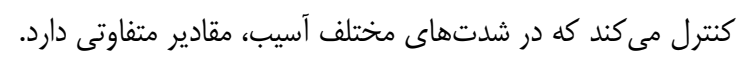

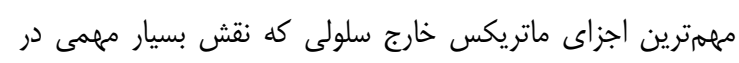

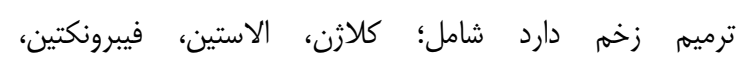

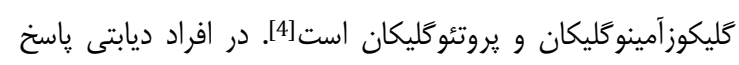

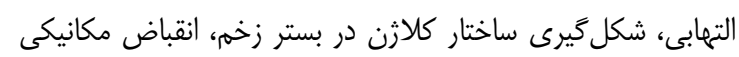

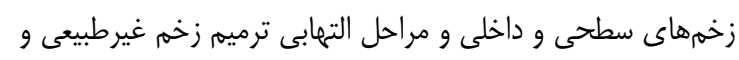

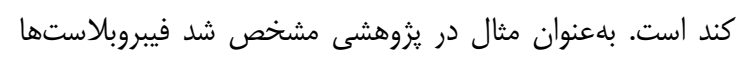

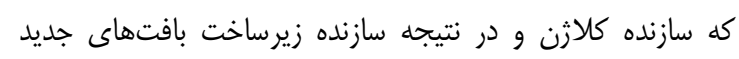

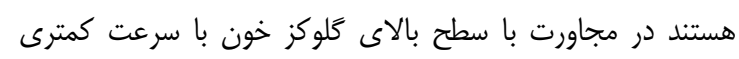

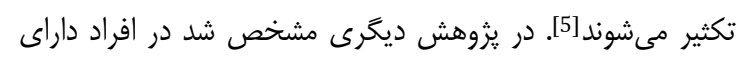

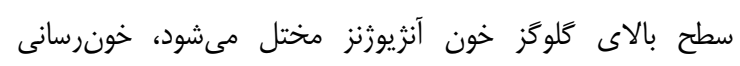

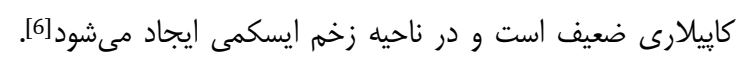

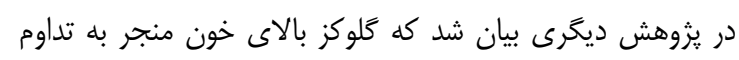

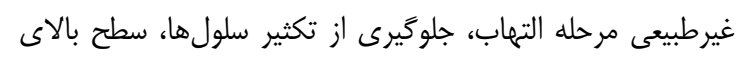

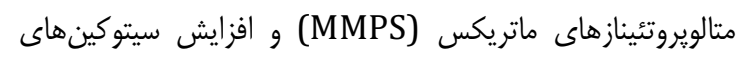

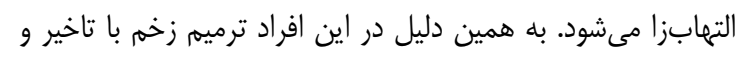

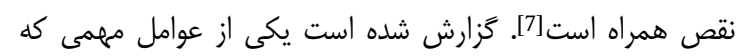

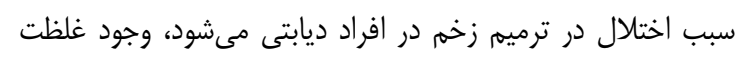

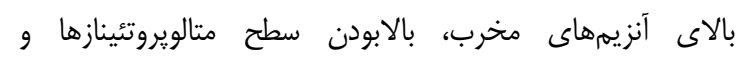

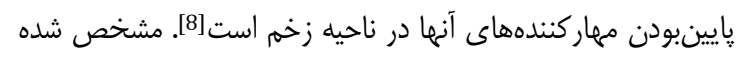

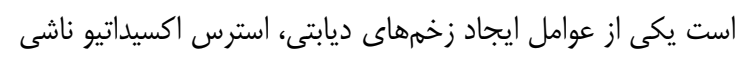

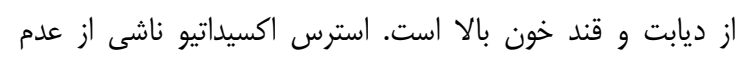

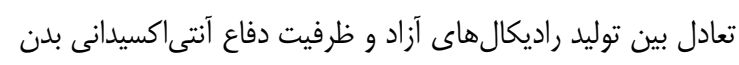

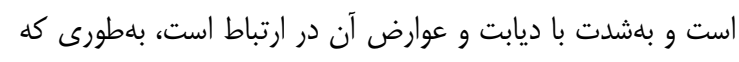

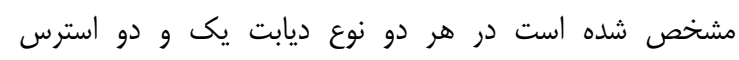

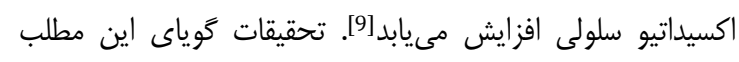

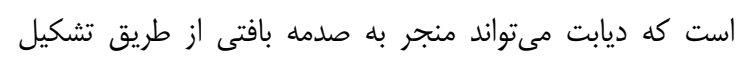

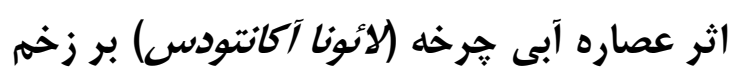

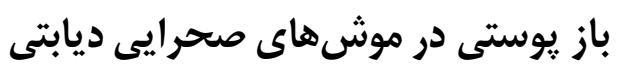

PhD راهله رهباريان

كروه زيستشناسى، دانشكده علوم، دانشخاه يِيام نور، تهران، ايران

حشمت سيهرىمقدم PhD

كروه كشاورزى، دانشكده علوم، دانشَاه يِيام نور، تهران، ايران

سيددامون صدوقى " PhD

باشكاه يزوهشكران جوان و نخبكان، واحد مشهد، دانشعاه آزاد اسلامى، مشهد،

ايران

جكيده

اهداف: تاخير در ترميم زخم از عوارض شايع بيمارى ديابت است. عصاره

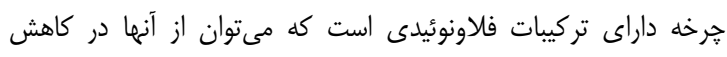

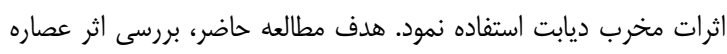

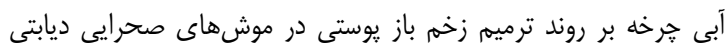

بود.

مواد و روشها: در اين يثوهش تجربى، بس سر موش صحر ايى نر نزاد

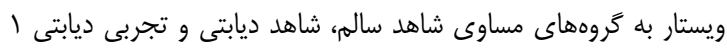

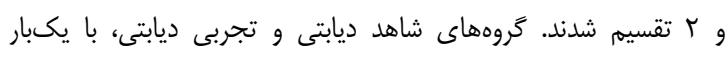

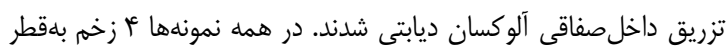

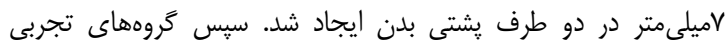

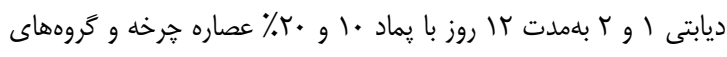

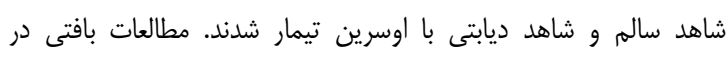

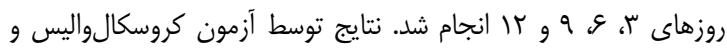

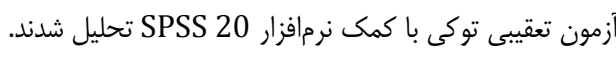

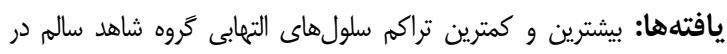

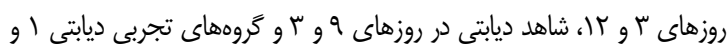

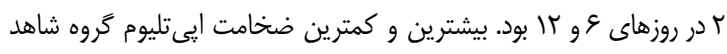

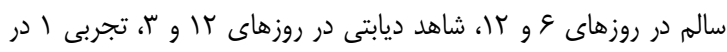

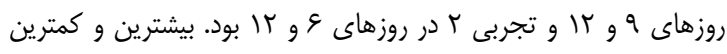

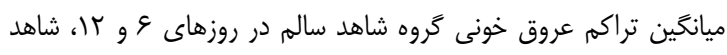

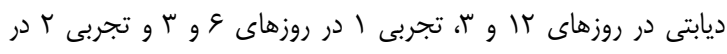

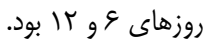
نتيجلَيرى: تيمار موضعى عصاره آبى خرخه موجب تسريع روند التيام زخمهاى ديابتى مىشود. كليدوازهها: زخمه، ديابت، يوست، موش صحر ايى

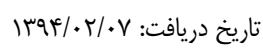

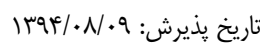
damoon.sadughi@gmail.com : تاريخ بذيرش:

مقدمه - مق

ديابت شامل تروهى از اختلالات متابوليكى است كه با افزايش

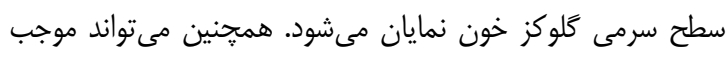
دوره rT، شماره ا، زمستان IraF فصلنامه افق دانش 


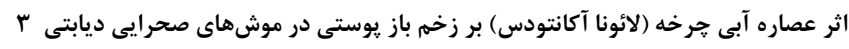

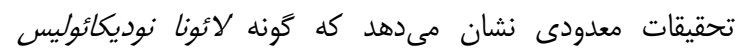
(Launaea nudicaulis)

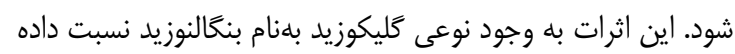

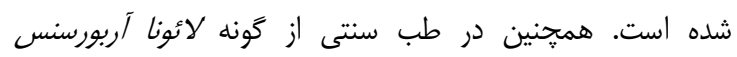

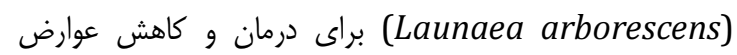

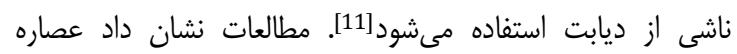

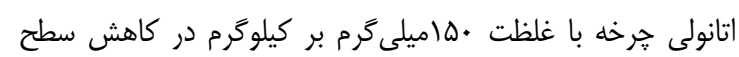

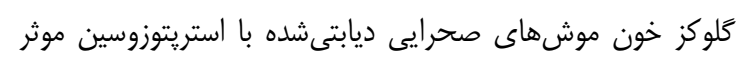

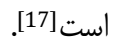

با توجه به خواص آنتى اكسيدانى خرخه و نقش موثر آن در كالب كاهش

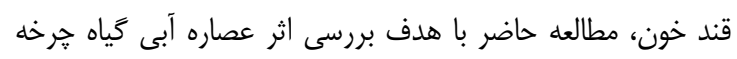
بر روند ترميم زخم باز يوستى در موشهاى صحاف صحرايى ديابتى انجام

\section{مواد و روشها}

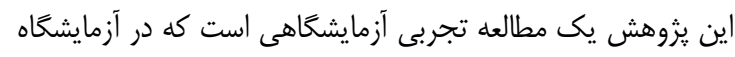

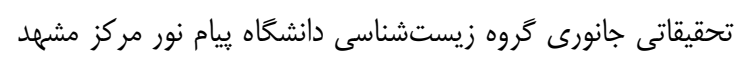

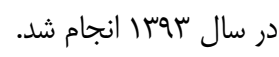

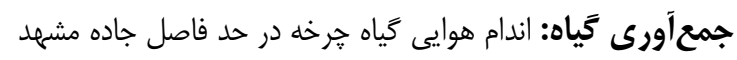

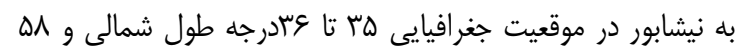

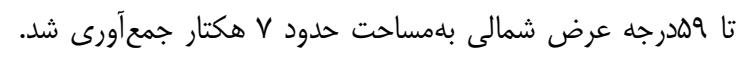

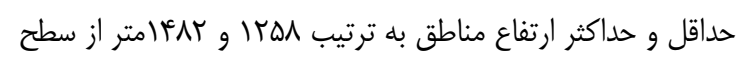

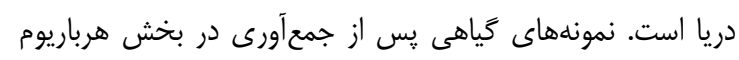

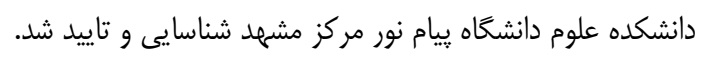

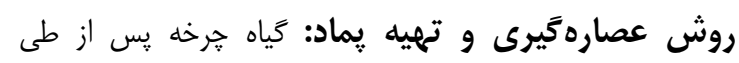

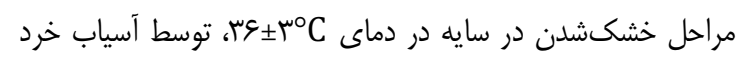

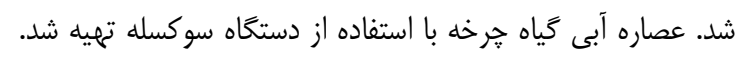

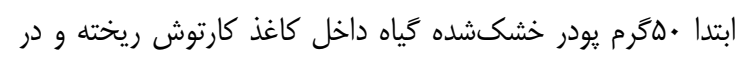

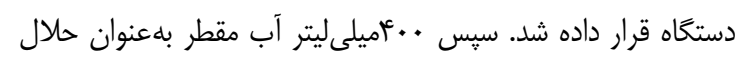

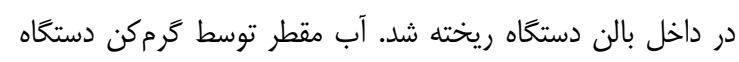

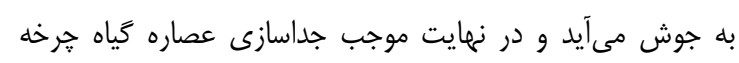

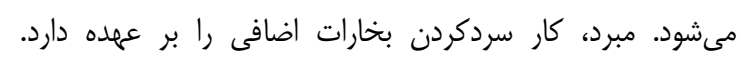

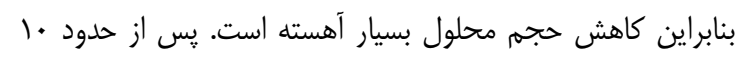

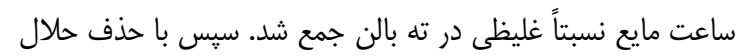

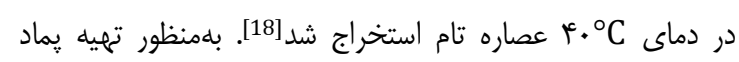

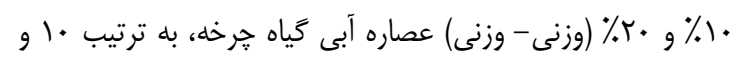

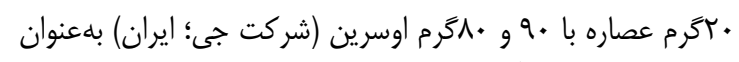

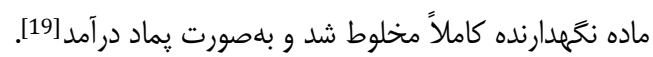

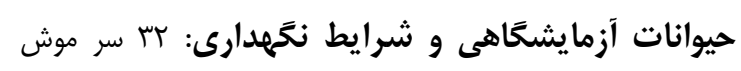

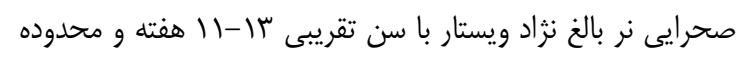

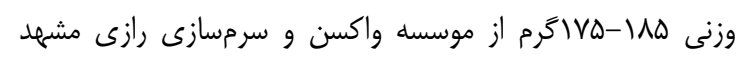

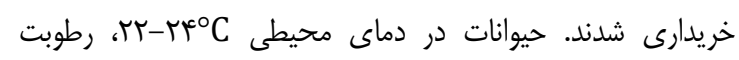

كروههاى بازى بين كروههاى كربونيل قند و كروههاى آمينى انر عاره

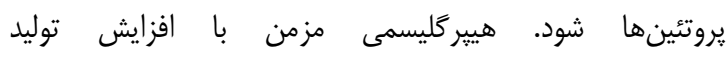

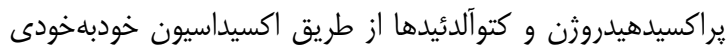

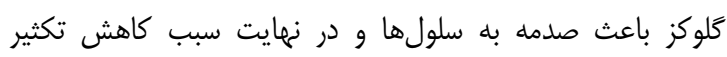

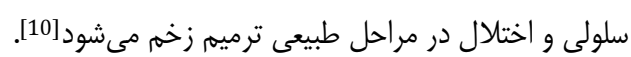

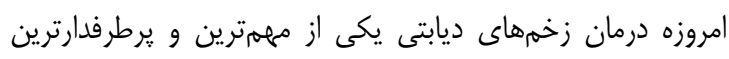

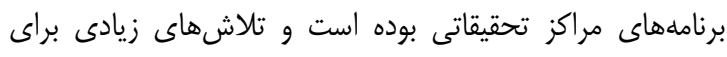

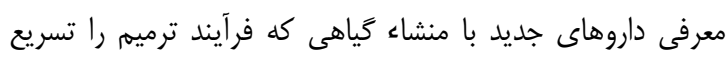
مىبخشند، صورت مى كيرد. خرخه (Launaea acanthodes)

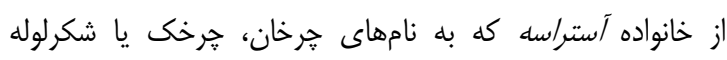

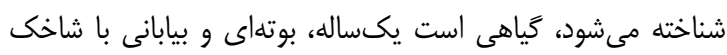

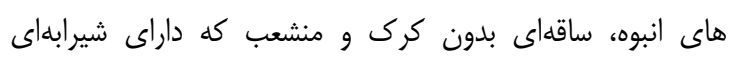

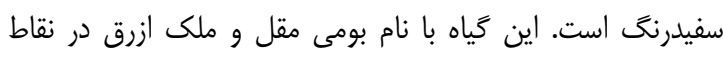

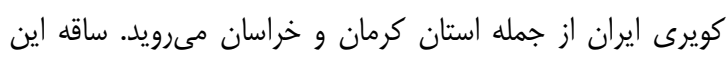

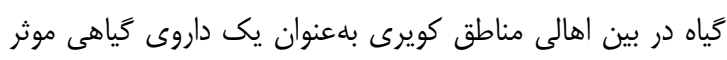

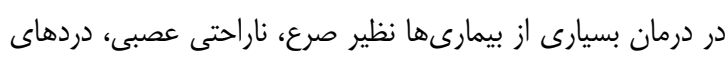

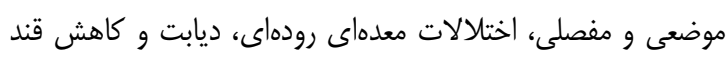

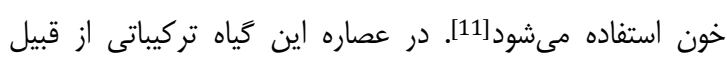

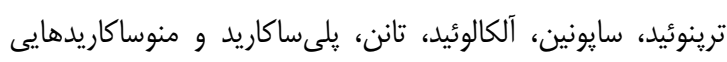

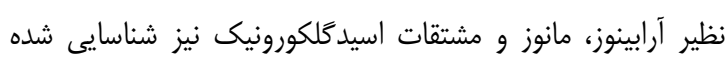

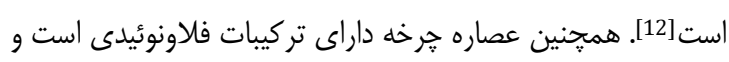

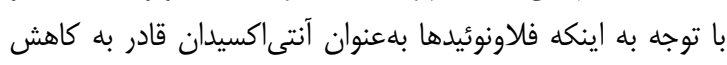

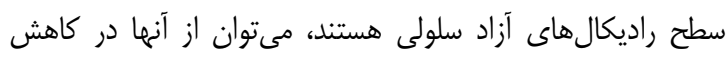

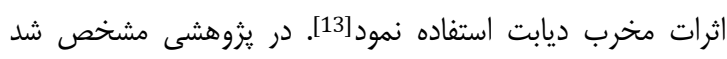

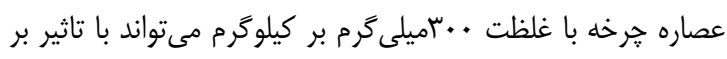

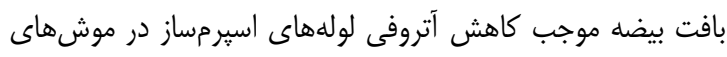

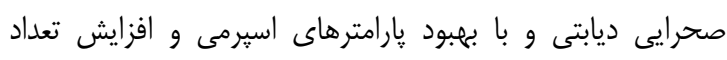

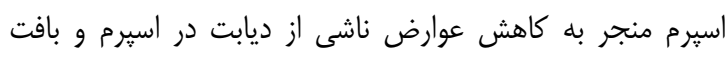

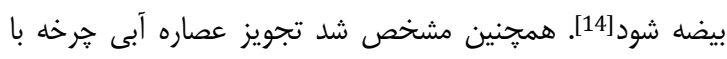

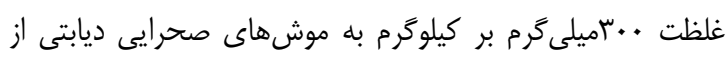
طريق افزايش تعداد و حجم جزاير لانكر هانس كه احتر احتمالاً در نتيجه

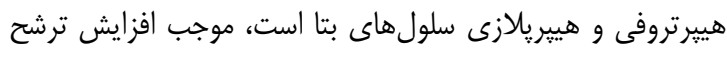

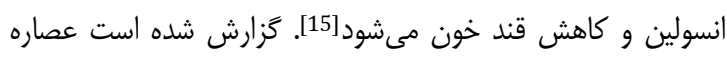

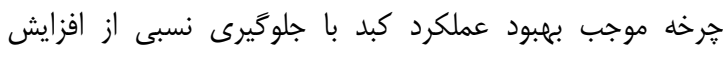

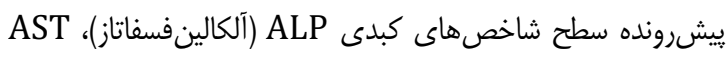

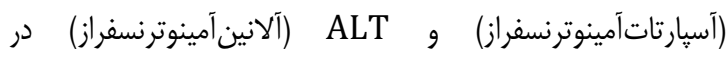

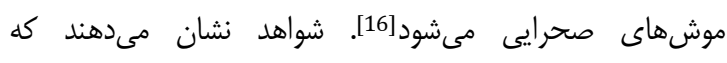

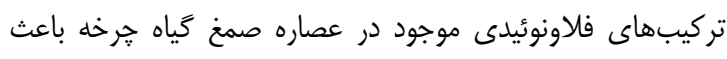

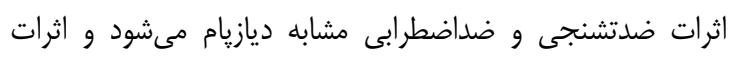

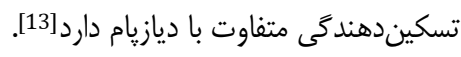

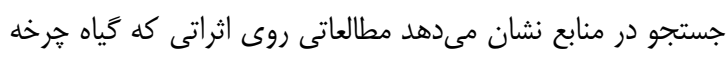

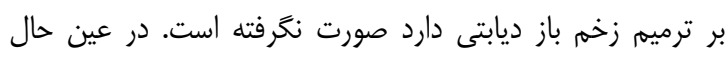


توسط ميكروسكوף نورى (Olympus CX21؛ زاين) با بإئا

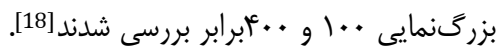

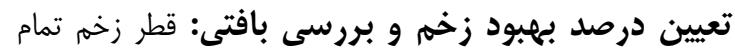

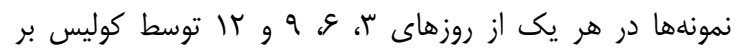

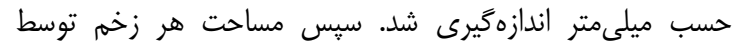

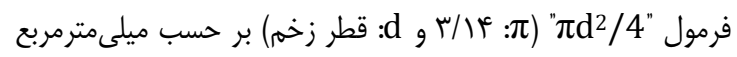

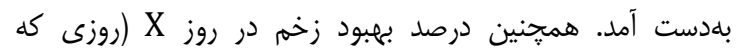

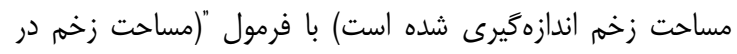

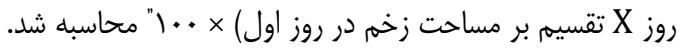

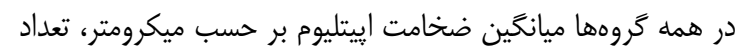

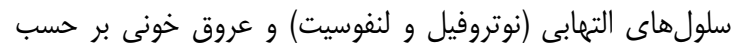

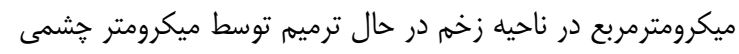

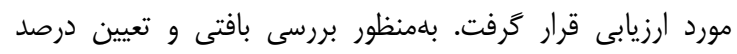

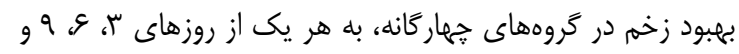

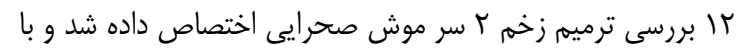

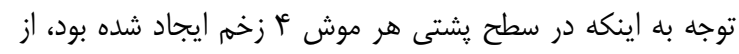

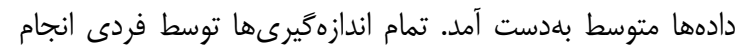

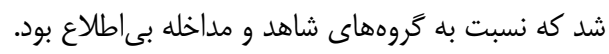

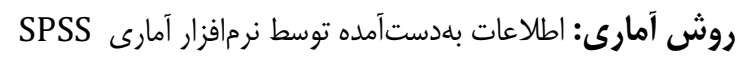

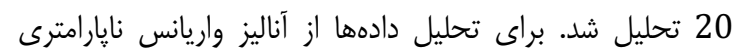

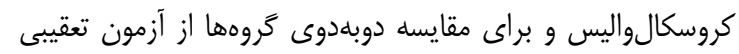

توكى استفاده شد.

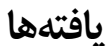

سلولهاى التهابى: بيشترين و كمترين ميانكَين تراكم سلولهاى

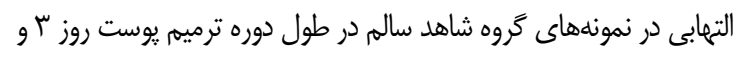

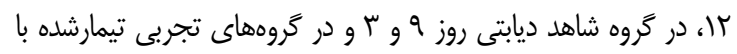

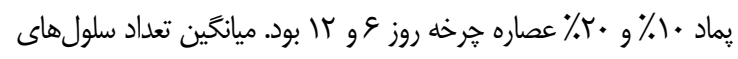

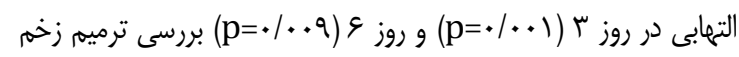

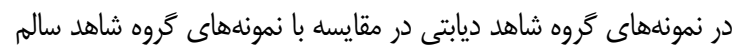

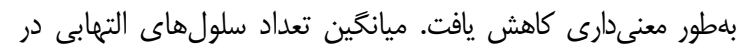

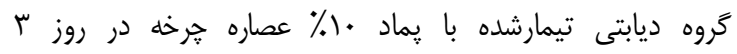

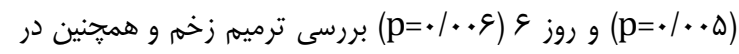

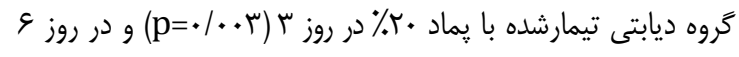

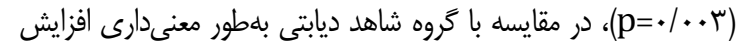

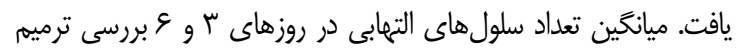

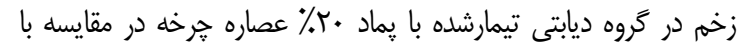

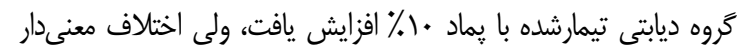

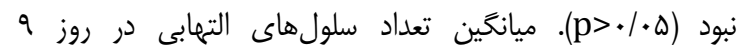

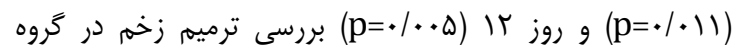

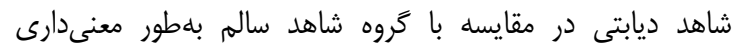

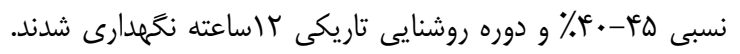

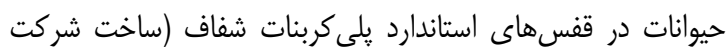

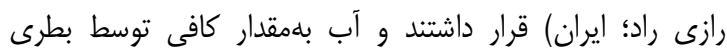

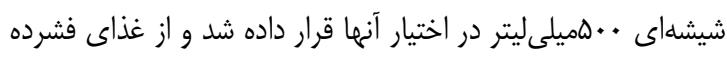

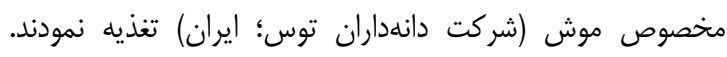

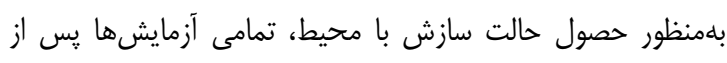

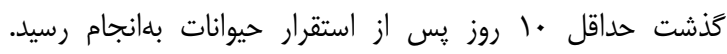

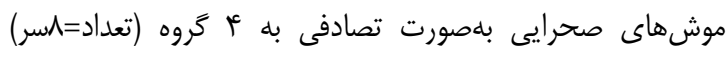

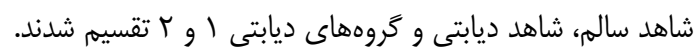
روش ايجاد ديابت تجربى: مدل تجربى ديابت دابت (ديابت وابسته

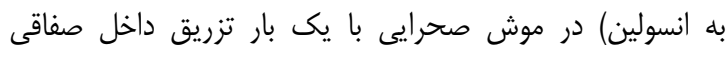

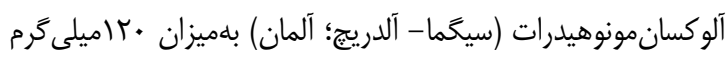

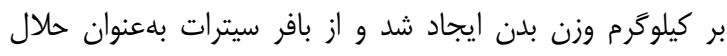

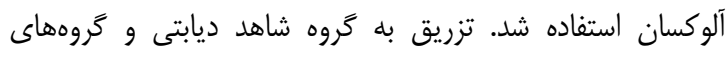

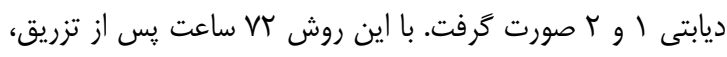

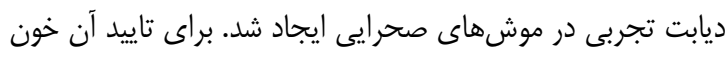

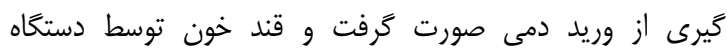

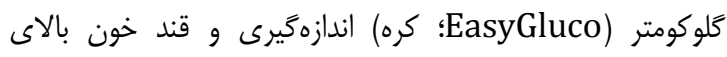

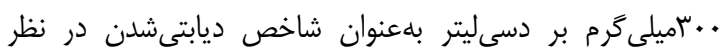

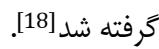

روش ايجاد زخم: با توجه به اينكه مطالعه روى ديابت مزمن

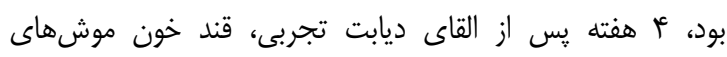

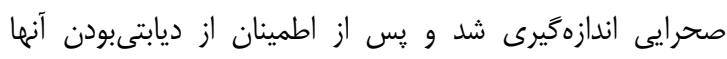

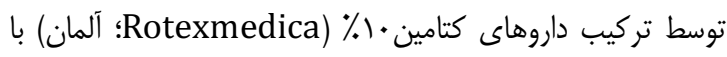

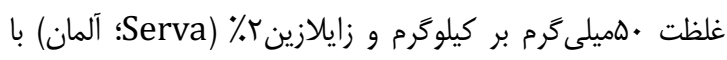

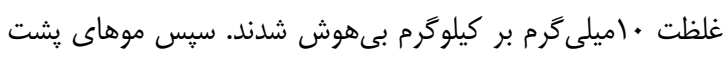

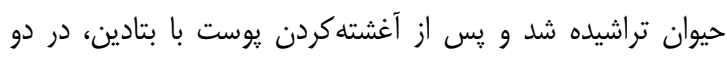

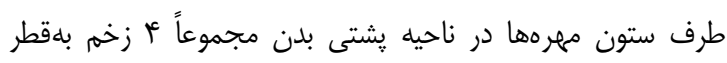

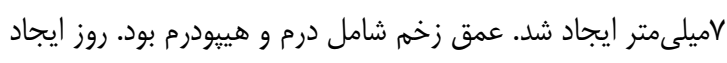

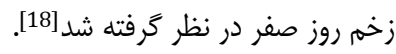

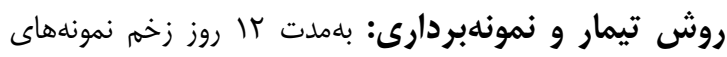

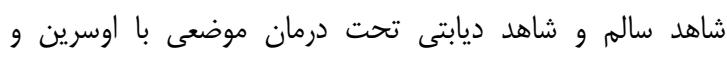

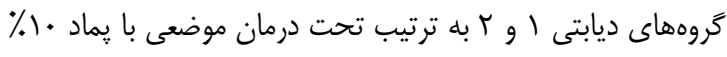

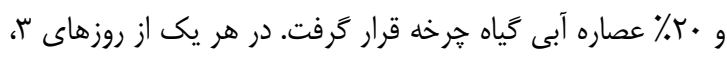

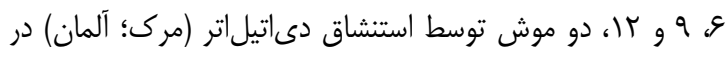

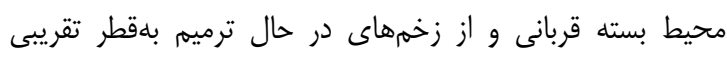

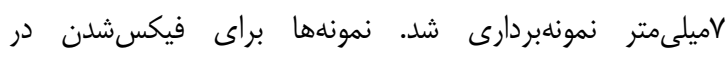

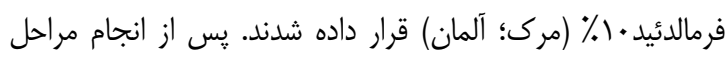

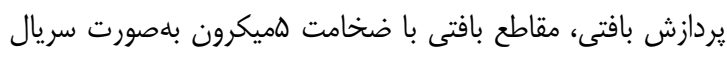

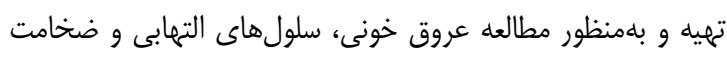

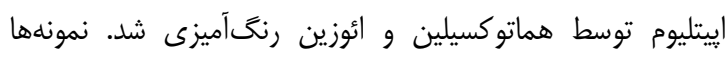




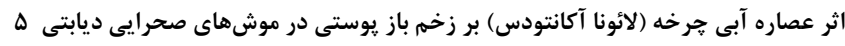

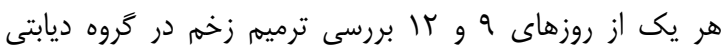

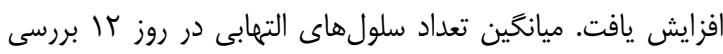

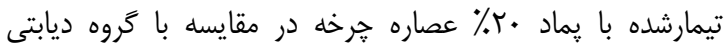

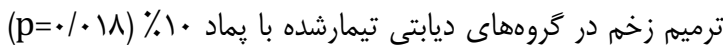

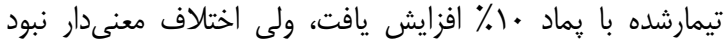

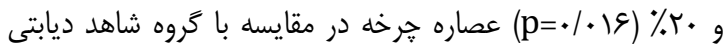

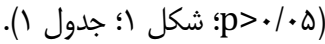

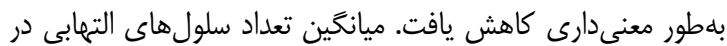

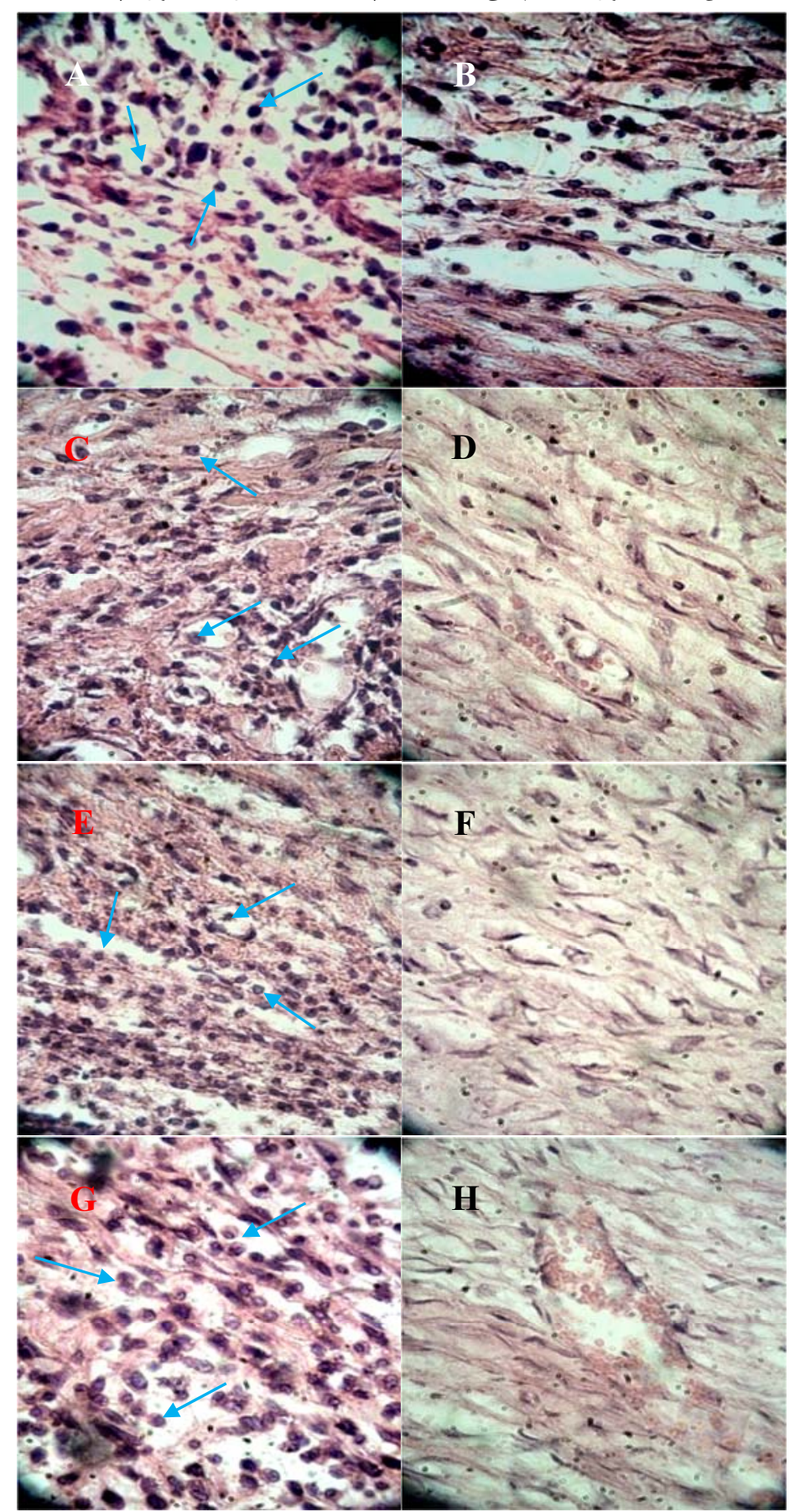

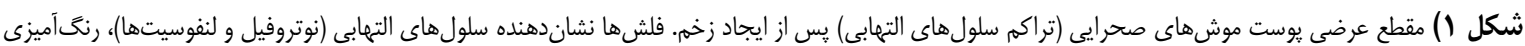

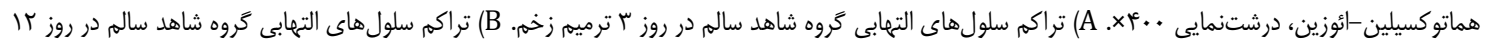

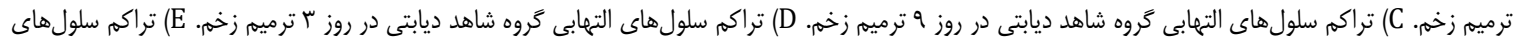

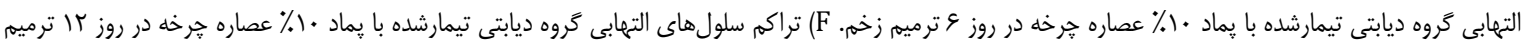

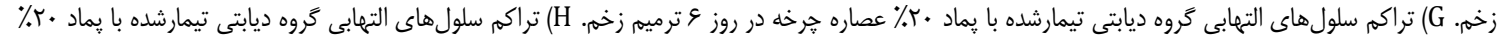
عصاره خرخه در روز با ترميم زخمه. 


\begin{tabular}{|c|c|c|c|c|}
\hline 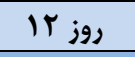 & ( ) & ( & (روز r & كَروههاى مورد مطالعه \\
\hline & & & & ميانكين تراكم سلولهاى التهابى (تعداد بر ميكرومتر مربع) \\
\hline$\varphi / \cdots \pm 1 / 19$ & $|T / R T \pm r / \Delta|$ & $r \Delta / \cdots \pm r / \cdots$ & $M \backslash / \varepsilon \varepsilon_{ \pm} r / \Delta \mid$ & 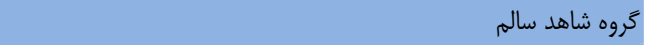 \\
\hline $\mid \varepsilon / \cdot \cdot \pm r / \cdot r$ & $r \cdot / \cdot \cdot \pm r / \cdot$ & $\mid f / \varepsilon 9 \pm \Psi / \Delta V$ & $11 / 9 \varepsilon_{ \pm} r / . \cdot$ & كروه شاهد ديابتى \\
\hline $1 \cdot / K+1 / \Delta 1$ & $\mid N / € q \pm Y / \cdot$. & $r</ r \pm F / r \mid$ & $r r / \cdots \pm r / \cdot$ & تجربى (عصاره • (1\%) \\
\hline \multirow[t]{2}{*}{$11 / \cdot \cdot \pm 4 / 19$} & $r / / 9 \varphi_{ \pm} r / \Delta V$ & $r \varepsilon / 98 \pm r / .$. & $r / T \pm r / \Delta 1$ & تجربى (عصاره •r\%) \\
\hline & & & & ميانكين ضخامت ايىتليوم (ميكرومتر) \\
\hline$\Gamma T / \Delta \Delta \pm \Psi / \Gamma \Lambda$ & $\Delta r / \mu I \pm T / V \Lambda$ & $A \leftarrow / T Y \pm \Delta / 11$ & $\Delta N / N \pm \pm F / \cdot 9$ & 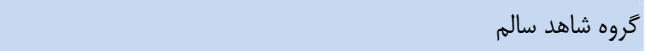 \\
\hline 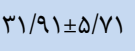 & $r \cdot / \varepsilon \Lambda \pm r / q \tau$ & $r E / T T \pm T / R T$ & $r \cdot / l i \pm r / F r$ & كروه شاهد ديابتى \\
\hline$r \cdot / \Delta \varepsilon \pm r / \Delta \Lambda$ & $\mu N / V \Delta \pm r / 9\rangle$ & $r r / 19 \pm F / \Delta$. & $r M / \cdot r \pm r / r q$ & تجربى (عصاره •1\%) \\
\hline$r N / T Q \pm T / N T$ & $r \varepsilon / 01 \pm \Gamma / 9)$ & $r q / \varsigma q \pm r / \wedge 1$ & $r \Delta / \Delta r \pm r / r \Lambda$ & تجربى (عصاره •r/\%) \\
\hline \multicolumn{5}{|r|}{ ميانكَين تراكم عروق خونى (تعداد بر ميكرومتر مربع) } \\
\hline$r / G T_{ \pm} \cdot / T \Lambda$ & $\tau / r \omega \pm 1 / \Delta V$ & $\varepsilon / \cdots \pm r / T \varepsilon$ & $\Delta / \mathcal{E} \nabla \pm 1 / I$ & كروه شاهد سالم \\
\hline$r / r \Lambda \pm r / q \Lambda$ & 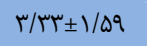 & $r / \cdot \Lambda \pm 1 / / f$ & $r / \widetilde{H} \pm \cdot / \Lambda V$ & كروه شاهد ديابتى \\
\hline$r / V I \pm 1 / \Delta V$ & $r / \cdot r \pm 1 / r)$ & $r / F \Delta \pm r / / f$ & $\left|r / \varepsilon_{ \pm} \cdot\right| q \mid$ & تجربى (عصاره •.(\%) \\
\hline $1 / \Delta \xi_{ \pm} \cdot /{ }^{+} \gamma$ & $r / \cdot \cdot \pm / / D Q$ & $r / 4 T \pm I / I T$ & $r / G T \pm r / r \Lambda$ & تجربى (عصاره • +r\%) \\
\hline
\end{tabular}

جدول r) ميانگين قطر زخم، مساحت زخم و درصد بهبودى زخم در بين گروههاى مورد مطالعه در طول دوره بازسازى يوست (تعداد در هر گروه= شسر)

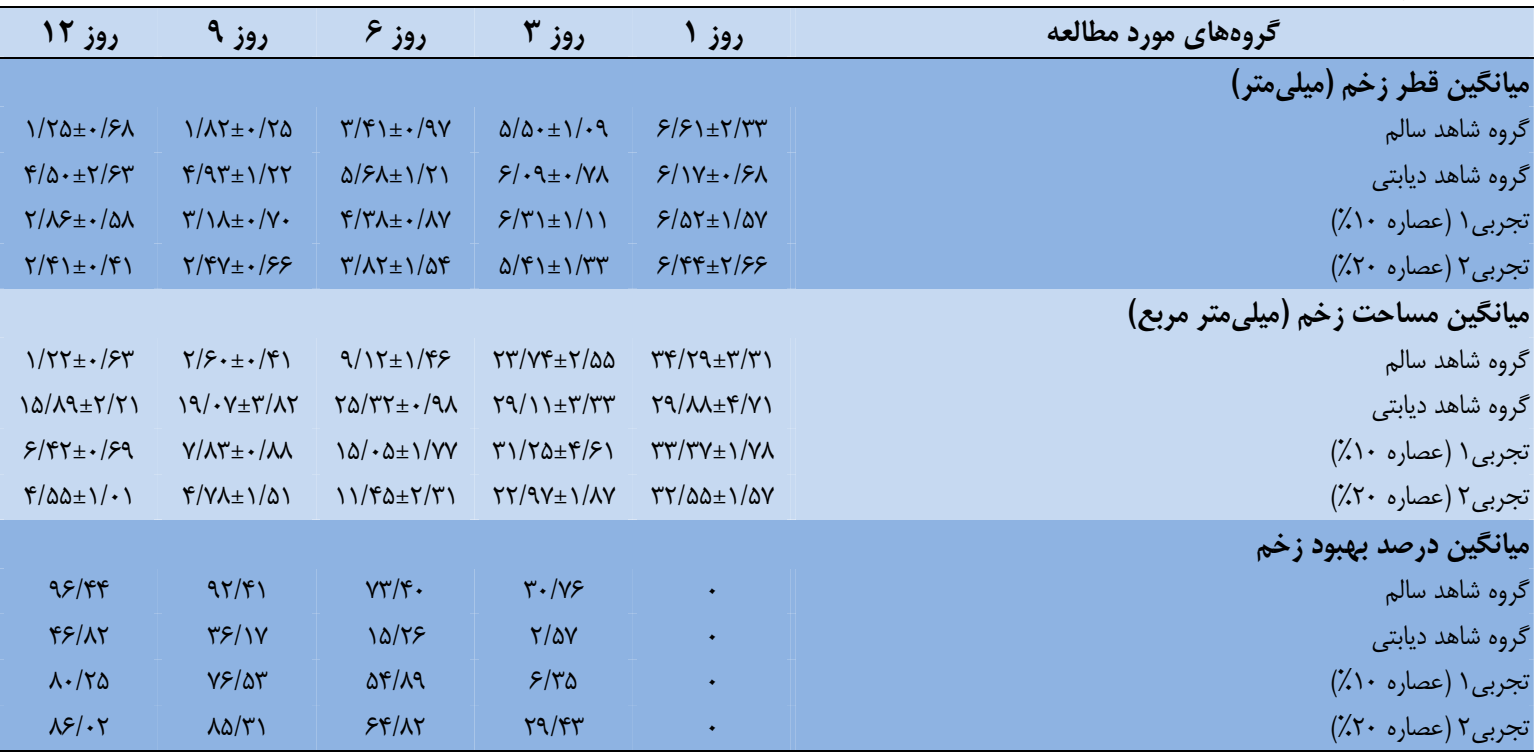

بلهور معنىدارى افزايش يافت. ميانخين ضخامت إيىتليوم در هر

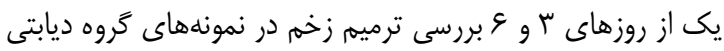

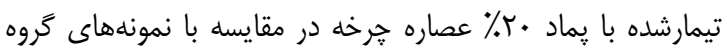

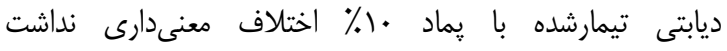

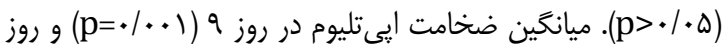

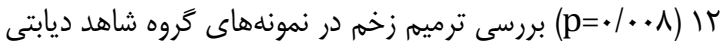

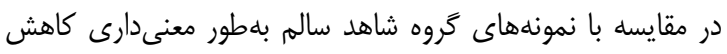

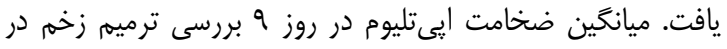

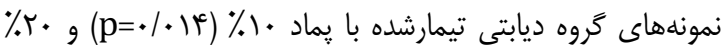

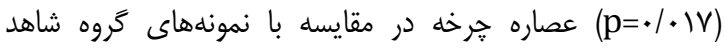
ديابتى بلهور معنىدارى افزايش يافت.
ايیىتليزاسيون: بيشترين و كمترين ميانخين ضخامت إيىتليوم در نمونههاى گروه شاهد سالم در طول دوره ترميهم يوست روز

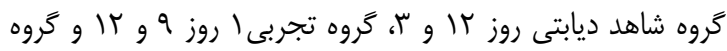

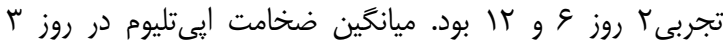

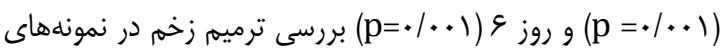
گروه شاهد ديابتى در مقايسه با نمونههاى گروه شاهد سالم بلهطور

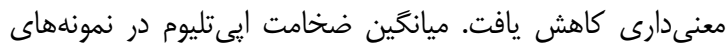

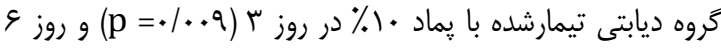

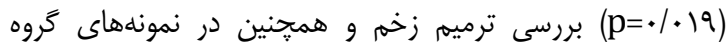

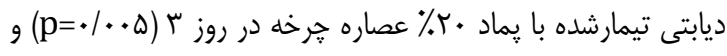

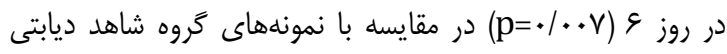

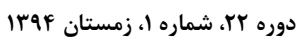
فصلنامه افق دانش 
V اثر عصاره آبى هرخه (لائونا آكانتودس) بر زخم باز يوستى در موشهاى صحرايى ديابتى

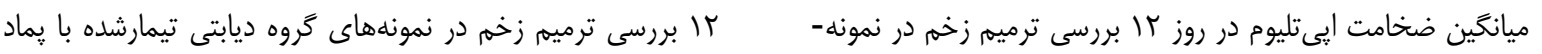

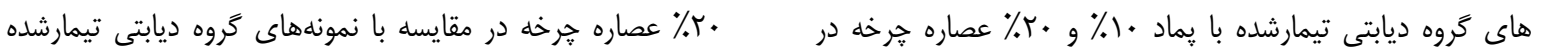

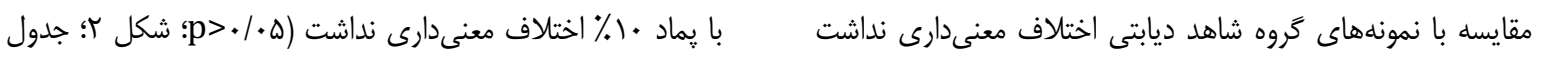

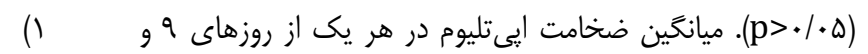
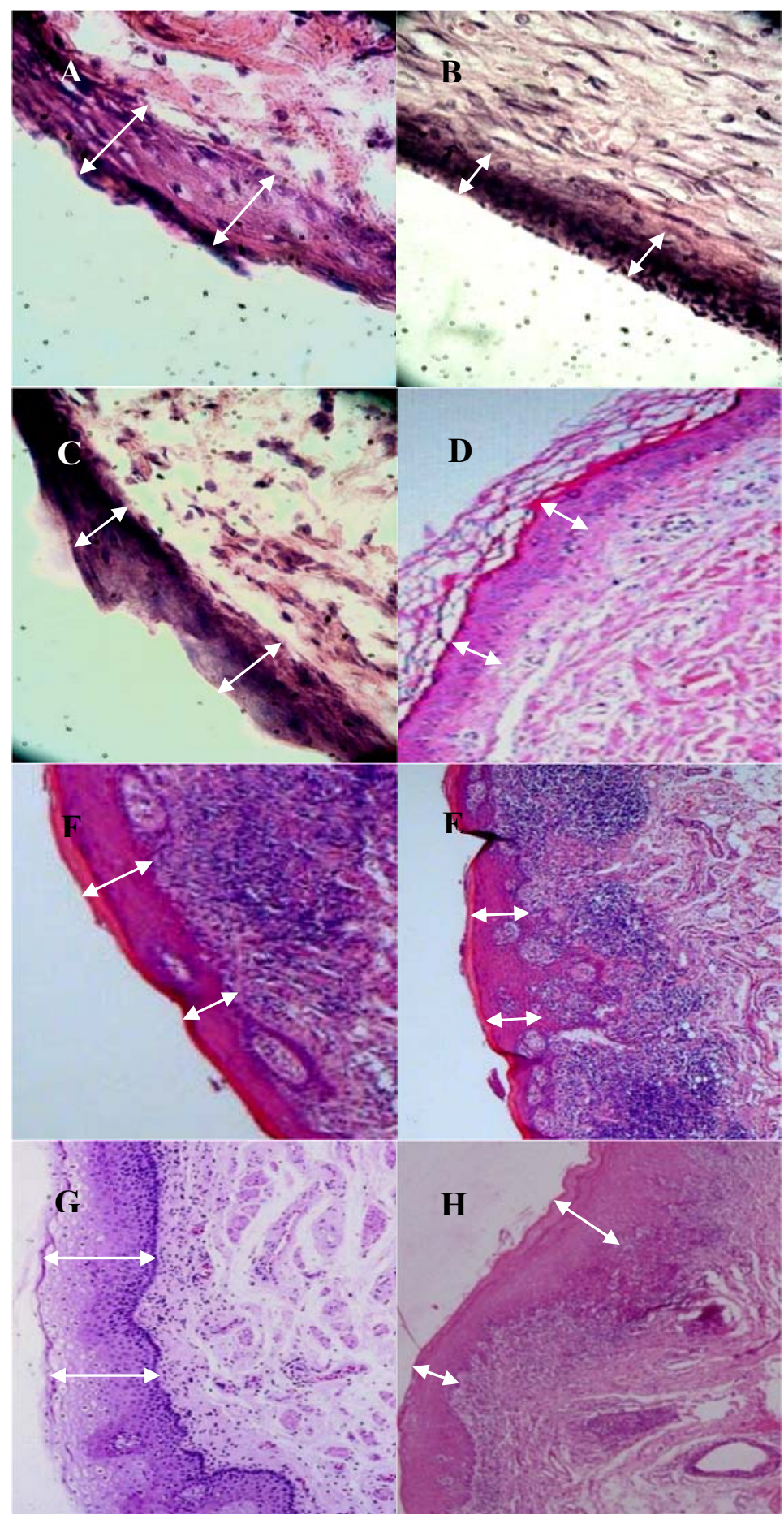

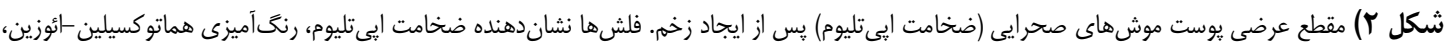

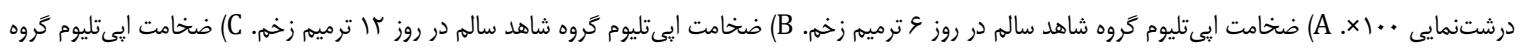

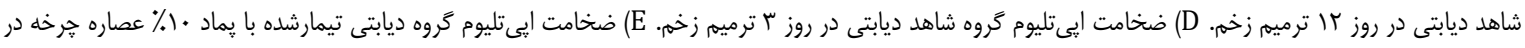

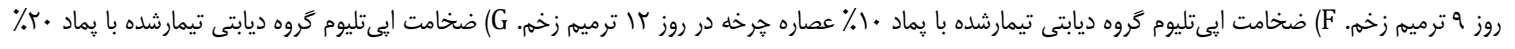

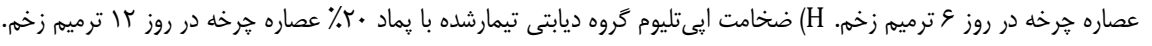


^ راهله رهباريان و همكاران

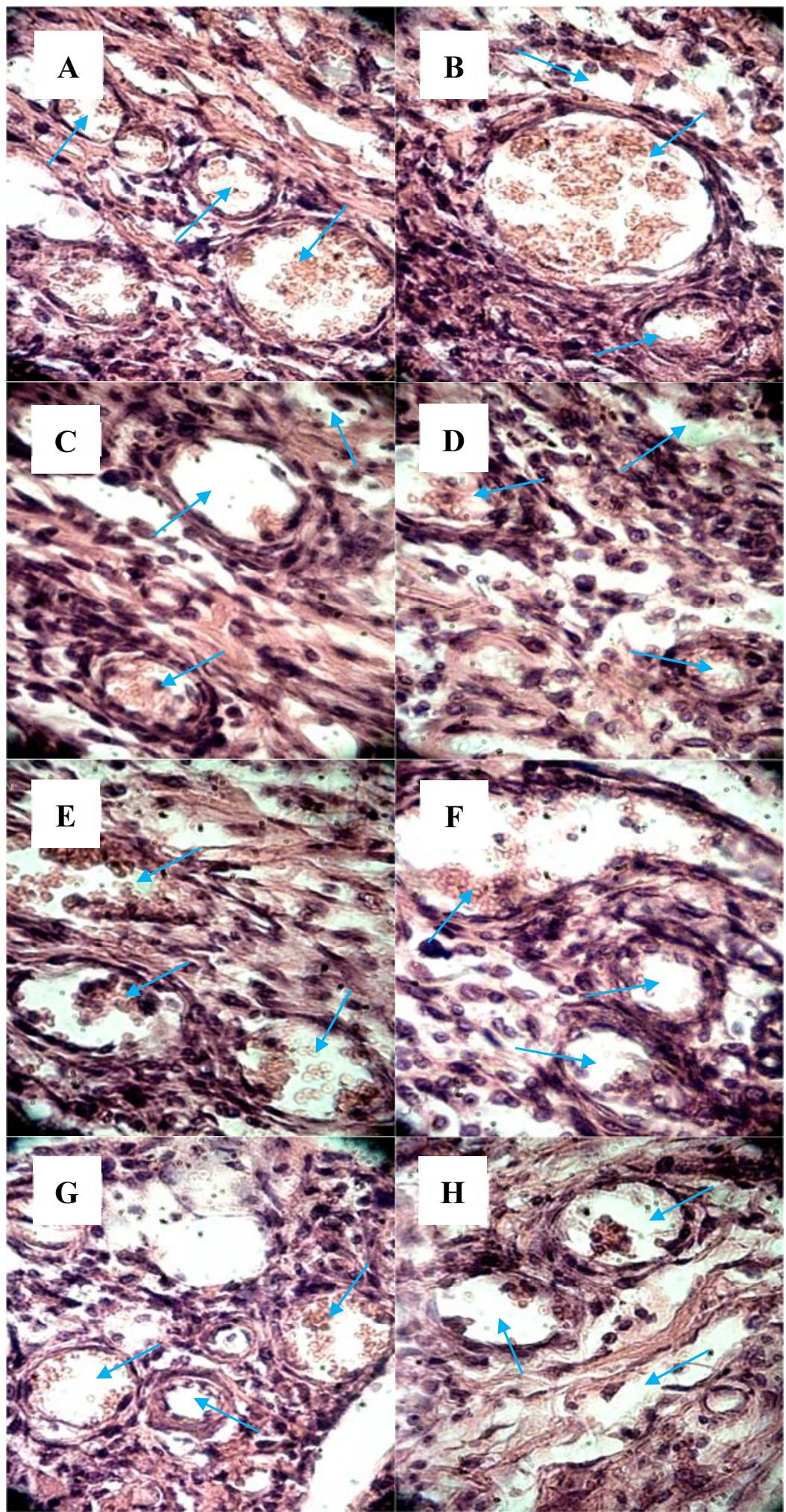

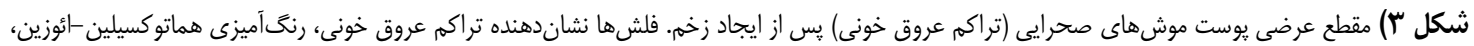

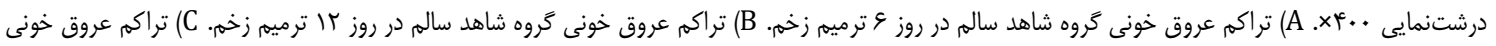

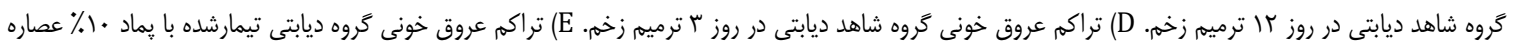

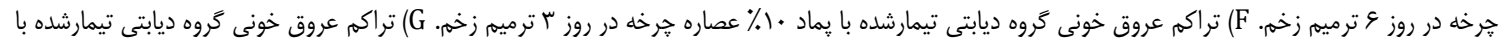

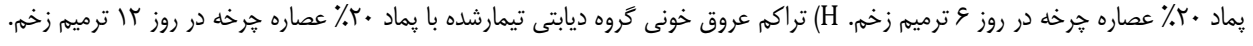


اثر عصاره آبى جرخه (لائونا آكانتودس) بر زخم باز يوستى در موشهاى صحرايى ديابتى 9

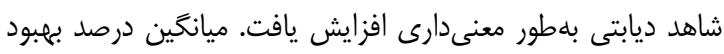

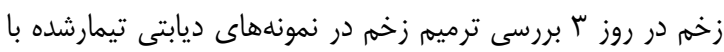

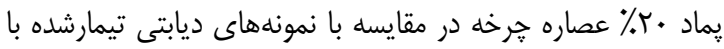

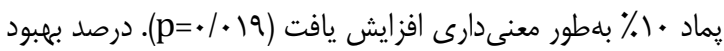

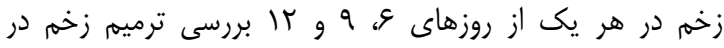

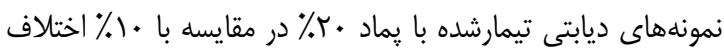

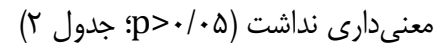

بحث

در اين يزوهش، اثر عصاره آبى گياه جرخه بر روند ترميه زخم باز يوستى در موشهاى صحرايى ديابتى مورد بررسى قرار گرفت.

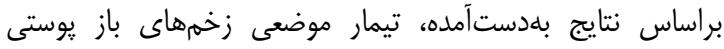

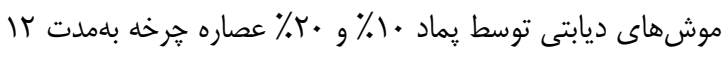

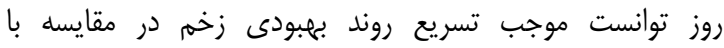

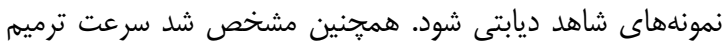

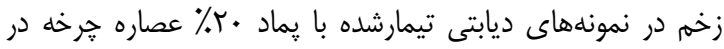

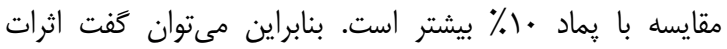

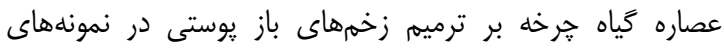

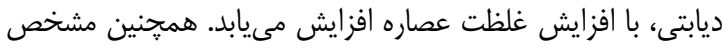

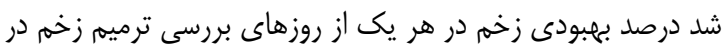

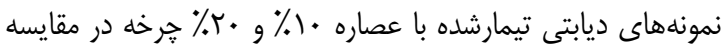

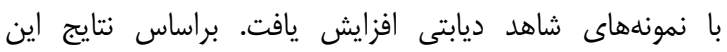
يثوهش، ديابت مىتواند موجب كاهش تراكم سلولهاى التهابى،

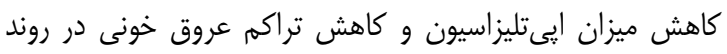

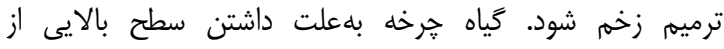

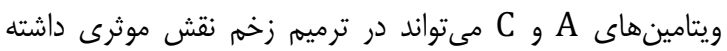

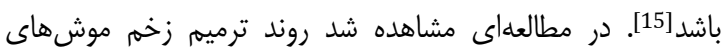
ديابتى كه تحت درمان موضعى با ويتامين A بودند افزايش يافت. همجنين مشاهده شد كه درمان موضعى با ويتامين A A

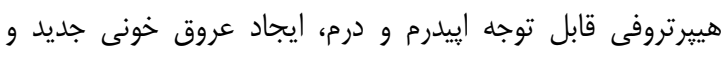
افزايش سلولهاى التهابى مىشود[20]. در مطالعهاى ديخر مشاهده

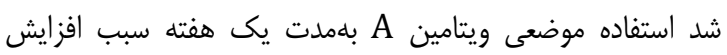

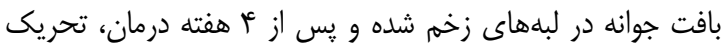
بيشتر بافت جوانهاى، بافت عروقى جديد و سنتز كلاثن جديد

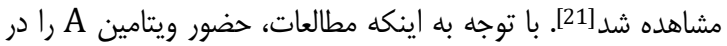

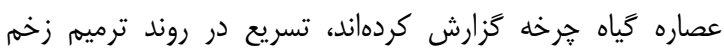
نمونههاى ديابتى را مىتوان به ويتامين A موجود در عصاره اين

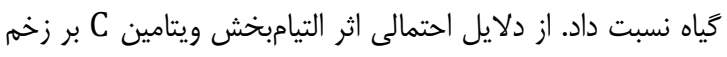
باز يوستى كه يكى از تركيبات موجود در گياه خرخه است، مى إتوان

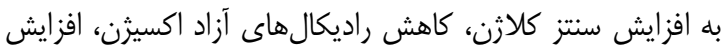
قابليت تكثير فيبروبلاستها، تشديد عمل بيكانهخوارى در موضع زخم، كاهش مرحله التهابى زخهم، افزايش عروقزايى و بهدنبال آن
تراكم عروق خونى: بيشترين و كمترين ميانخين تراكم عروق

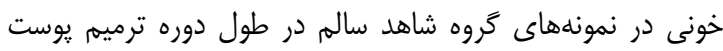

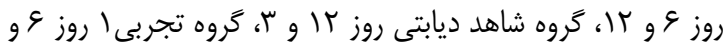

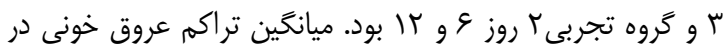

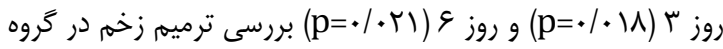

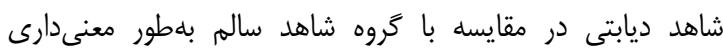

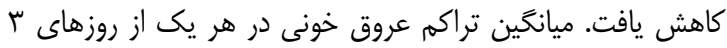

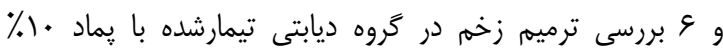
عصاره جرخه در مقايسه با گروه شاهد ديابتى اختلاف معنى ندارى

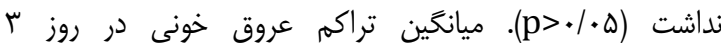

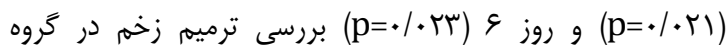

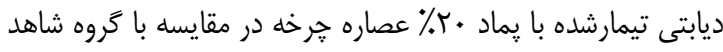

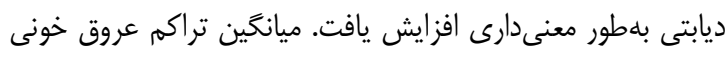

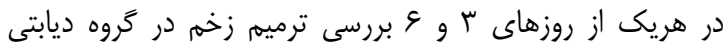

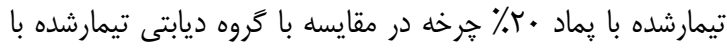

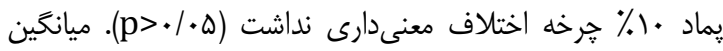

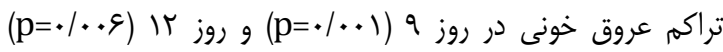
بررسى ترميم زخم در گروه شاهد ديابتى در مقايسه با گروه شاهو شاهد

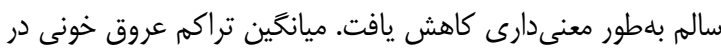

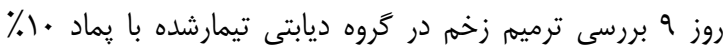

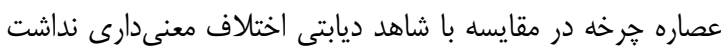

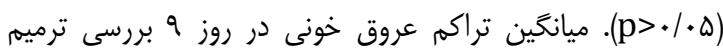

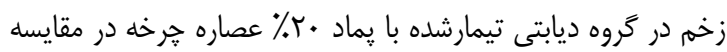

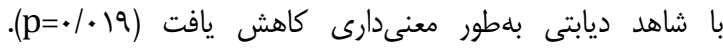

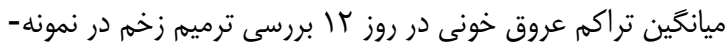

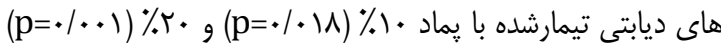

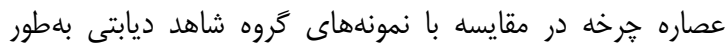
معنىدارى كاهش يافت و ميانگين تراكم عروق خونى در هر يك ده از

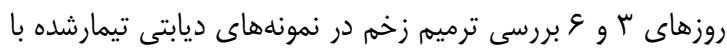

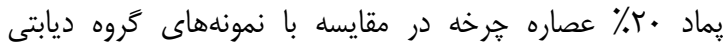

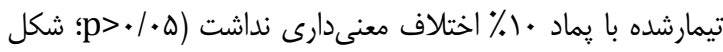

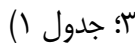

درصد بهبود زخم: ميانگين درصد بهبود زخم در روز I (p)

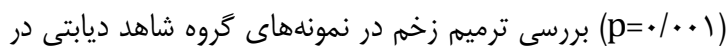

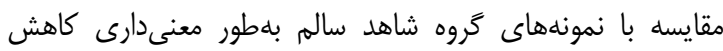

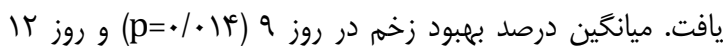

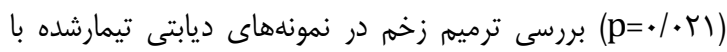

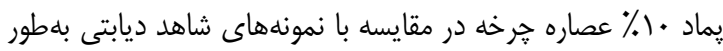

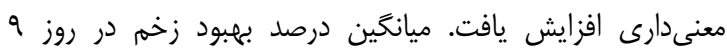

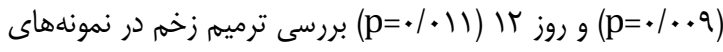

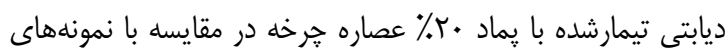


بلنظر مىرسد شايد قسمتى از اثرات التيامبخشى گياه هرخه احتمالاً

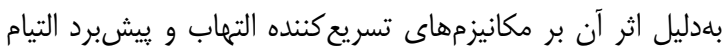

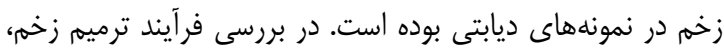

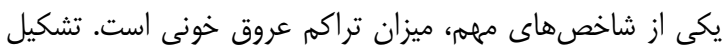

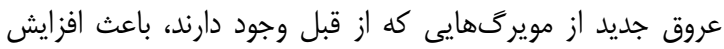

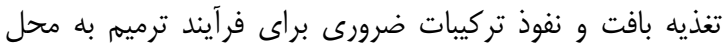

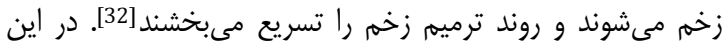

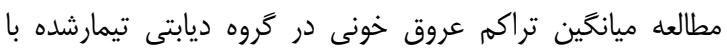

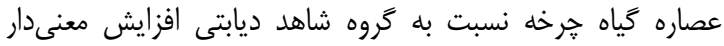

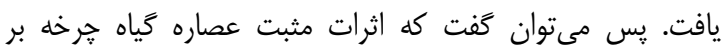

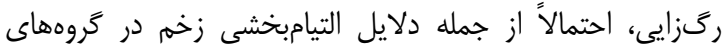

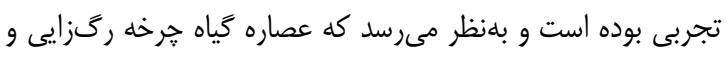

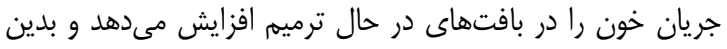

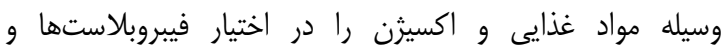
سلولهاى ايىتليال قرار مىدهد و باعث افزايش تكثير سلولى و إنيار

$$
\text { ترميهم ايیىتليوم مى شودا. }
$$

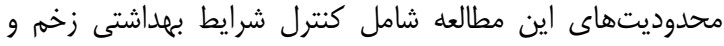

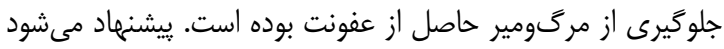

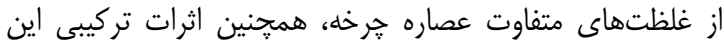
عصاره با موادى مانند عسل و روغنهاى حيوانى كه اثرات مفيدى

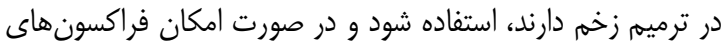

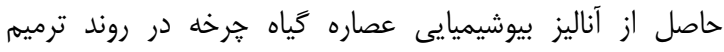
زخمهاى ديابتى مورد بررسى قرار گيرد.

\section{نتيجل كيرى}

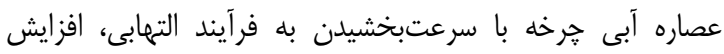
تكثير سلولهاى ايىتليومى و افزايش تشكيل عروق خونى نقش

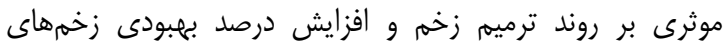

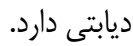

تشكر و قدردانى: بدين وسيله نويسندكان مقاله از تمام اساتيد

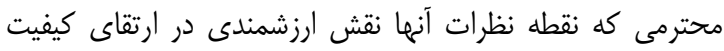
مقاله داشته است، سياسكز ارى و قدردانى مىنمايند.

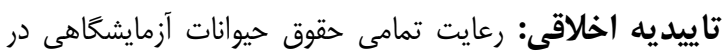

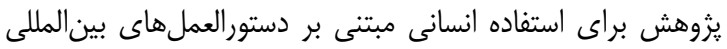

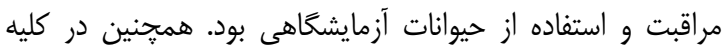

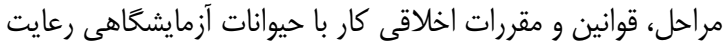

تعارض منافع: موردى از طرف نويسندكان بيان نشده است. منابع مالى: اين مقاله حاصل طرح ثروهشى مصوب دانشعاه بيام نور است. همجنين منابع مالى توسط دانشكاه يِيام نور تامين شده
افزايش خون و افزايش ثبات در غشاى سلولى اشاره كرد[22, 23.

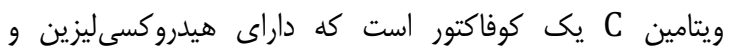

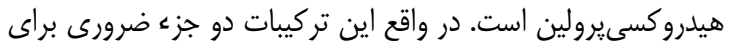

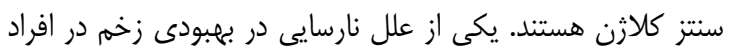

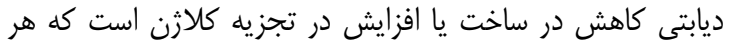

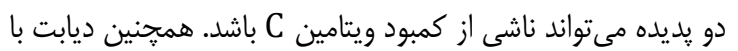
كاهش سطح ويتامين C در لكوسيتهاى تكهستهاى موجب إنائ

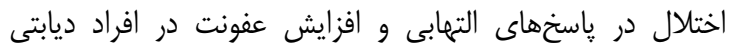
مىشود[24]. از سوى ديخر ديابت مزمن با كاهش سطح ويتامين

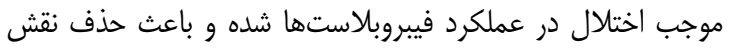
كوفاكتورى آن در ساخت كلازن مىشود. در نتيجه كلازن توليد نشده يا بلهورت غيرطبيعى توليد مىشود[25]. با توجه به به نتايج

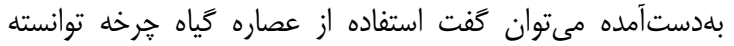

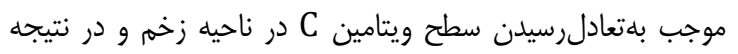
افزايش سرعت روند ترميم زخم شود. كزارش شده است أثرات آثرات

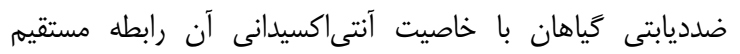

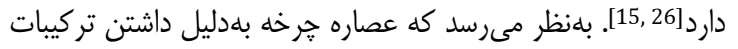

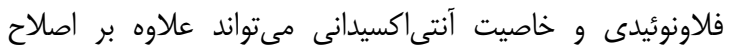

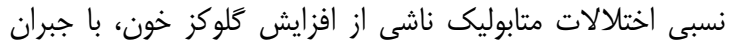
نقايص عملكردى بانكراس و افزايش ترشح انسولين، موجب كاهش إنش سطح سرمى كلوكز خون و بهبود شرايط استرس اكسيداتيو سلولى

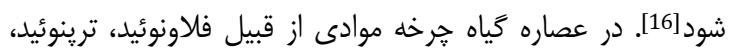
سايونين، آلكالوئيد و تانن شناسايى شده است [13]. اين مواد با اعمال

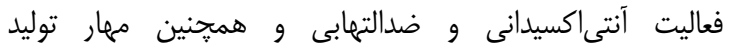
راديكالهاى آزاد كه در بيمارى ديابت بلصورت شايعى وجود دارئ دارد،

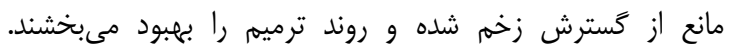

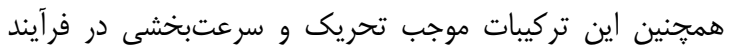

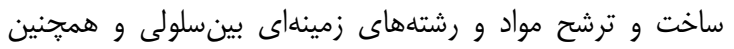

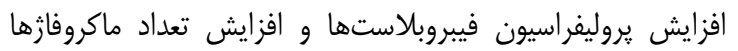

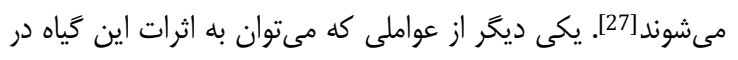

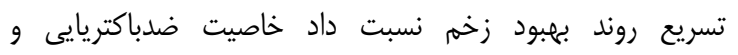

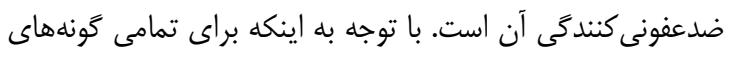

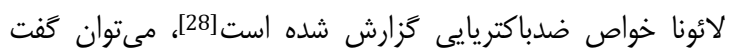

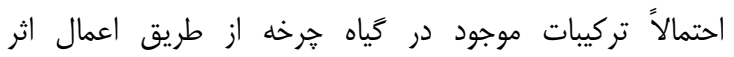

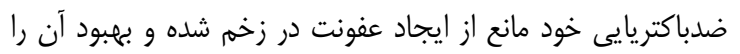
تسريع مى بخشد. افزايش خونرسانى و اكسيثرنرسانى به إنها محل

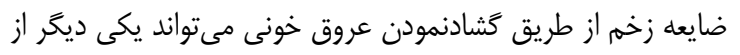

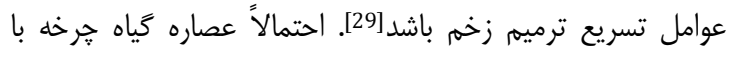

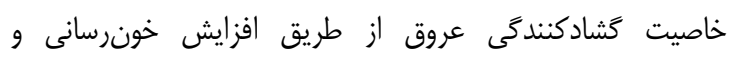

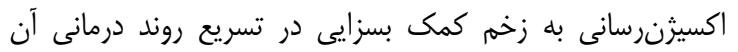

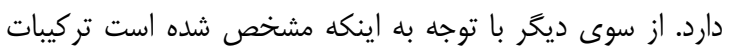
فلاونوئيدى داراى اثرات ضدميكروبى [30] و ضدالتهابى هستند [313، 


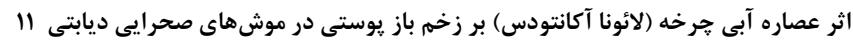

17- Behnam-Rassouli M, Ghayour N, Ghayour MM, Ejtehadi MM. Investigating the effects of hydroalcoholic extract of Launaea acanthodes on the serum levels of glucose, insulin, lipids and lipoproteins in stereptozotocin induced type I diabetic rats. Arak Med Univ J. 2012;14(6):48-56. [Persian]

18- Sadoughi SD. Effect of aqueous extract of Ferula assafoetida's resin on wound healing of streptozotocin induced diabetic rats. Q Horiz Med Sci. 2013;19(3):12935. [Persian]

19- Hoseini-Tahmasbi M, Hoseini-Tahmasbi S, Karamidehkordi A, Delaram M, MalekAnzabi J, Fatahi F. Effect of Arnebia euchroma root extract on burn wound healing in Balb/c mice. J Shahrekord Univ Med Sci. 2013;15(4):5461. [Persian]

20- Kitano Y, Yoshimura K, Uchida G, Sato K, Harii K. Pretreament of topical all-trans acid is benefical for wound healing in genetically diabetic mice. Arch Dermatol Res. 2001;293(10):515-21.

21- Lateef H, Abatan OI, Nadeem Aslam M, Stevens MJ, Varani J. Topical pretreatment of diabetic rats with alltrans retinoic acid improves healing of subsequently induced abrasion wounds. Diabetes. 2005;54(3):855-61.

22- Ringsdorf WM Jr, Cheraskin E. Vitamin C and human wound healing. Oral Surg Oral Med Oral Pathol. 1982;53(3):231-6.

23- Jagetia GC, Rajanikant GK, Baliga MS, Rao KV, kumar P. Augmentation of wound headling by ascorbic acid treatment in mice exposed to gamma- raditition. Int J Radiat Biol. 2004;80(5):347-54.

24- Pinnel SR, Murad S, Darr D. Induction of Collagen Synthesis by Ascorbic AcidA Possible Mechanism. Arch Dermatol. 1987;123(12):1684-6.

25- Nusgens BV, Humbert Ph, Rougier A, Colige AC, Haftek M, Lambert CA, et al. Topically applied vitamin C enhances the mRNA level of collagens I and III, their processing enzymes and tissue inhibitor of matrix metalloproteinase 1 in the human dermis. J Invest Dermatol. 2001;116(6):853-9.

26- Lukacinova A, Mojzis J, Benacka R, Keller J, Maguth T, Kurila P, et al. Preventive effects of flavonoids on alloxaninduced diabetes mellitus in rats. Acta Vet Brno. 2008;77:175-82.

27- Lodhi S, Singhai AK. Wound healing effect of flavonoid rich fraction and luteolin isolated from Martynia annua Linn on streptozotocin induced diabetic rats. Asian Pac J Trop Med. 2013;6(4):253-9.

28- Zellagui A, Gherraf N, Ladjel S, Hameurlaine S. Chemical composition and antibacterial activity of the essential oils from Launaea resedifolia L. Org Med Chem Lett.. 2012;2(1):2.

29- Tonnesen MG, Feng X, Clark RF. Angiogenesis in wound healing $J$ Investig Dermatol Symp Proc. 2000;5(1):40-6.

30- Wang L, Yang X, Qin P, Shan F, Ren G. Flavonoid composition, antibacterial and antioxidant properties of tartary buckwheat bran extract. Ind Crops Prod. 2013;49:312-7.

31- Feng R, Guo ZG, Yan CM, Li EG, Tan RX, Ge HM. Antiinflammatory flavonoids from Cryptocarya chingii. Phytochem. 2012;76:98-105.

32- Greaves NS, Ashcroft KJ, Baguneid M, Bayat A. Current understanding of molecular and cellular mechanisms in fibroplasia and angiogenesis during acute wound healing. J Dermatol Sci. 2013;72(3):206-17.

1- Matveyenko A, Vella A. Regenerative medicine in diabetes. Mayo Clin Proc. 2015;90(4):546-54.

2- Adams SB Jr, Sabesan VJ, Easley ME. Wound healing agents. Crit Care Nurs Clin North Am. 2012;24(2):255-60. 3- Bazrafshan A, Owji M, Yazdani M, Varedi M. Activation of mitosis and angiogenesis in diabetes-impaired wound healing by processed human amniotic fluid. J Surg Res. 2014;188(2):545-52.

4- Mott JD, Werb Z. Regulation of matrix biology by matrix metalloproteinases. Curr Opin Cell Biol. 2004;16(5):558-64.

5- Moura LI, Dias AM, Suesca E, Casadiegos S, Leal EC, Fontanilla MR, et al. Neurotensin-loaded collagen dressings reduce inflammation and improve wound healing in diabetic mice. Biochim Biophys Acta. 2014;1842(1):32-43.

6- Oviedo-Socarras T, Vasconcelos AC, Barbosa IX, Pereira NB, Campos PP, Andrade SP. Diabetes alters inflammation, angiogenesis, and fibrogenesis in intraperitoneal implants in rats. Microvasc Res. 2014;93:23-9.

7- Lobmann R, Zemlin C, Motzkau M, Reschke K, Lehnert H. Expression of matrix metalloproteinases and growth factors in diabetic foot wounds treated with a protease absorbent dressing. J Diabetes Complic. 2006;20(5):32935.

8- Thomas DR. Clinical management of diabetic ulcers. Clin Geriatr Med. 2013;29(2):433-41.

9- Schafer M, Werner S. Oxidative stress in normal and impaired wound repair. Pharmacol Res. 2008;58(2):16571.

10- Boulton AJ. The pathway to foot ulceration in diabetes. Med Clin North Am. 2013;97(5):775-90.

11- Hajinejad Boshroue R, Behnam Rassouli M, Tehranipour M, Gheybi F, Hajinejad Sh, Elahi Moghaddam Z. The effects of hydro- alcoholic extract of launaea acanthodes on the blood, Urine Albumin and Bilirubin levels in male hyperglycemic wistar rat. Iran J Endocrinol Metab. 2013;15(2):190-233. [Persian]

12- Piazza L, Bertini S, Milany J. Extraction and structural characterization of the polysaccharide fraction of Launaea acanthodes gum. Carbohydr Polym. 2010;79(2):449-54.

13- Karimidokht shahrbabaki A, Oryan Sh, Parivar K. Anticonvulsant activity of ethanolic extract and aqueous fraction of Launaea acanthodes gum in comparison with diazepam in mice. J Qhazvin Univ Med Sci. 2009;13(1):14-20. [Persian]

14- Rohbarian R, Sepehri Moghadam H, Sadoughi SD. Effect of Aqueous Extract of Launaea acanthodes on Testicular Tissue and Sperm Parameters in AlloxanInduced Diabetic Rats. Q Horiz Med Sci. 2015;21(1):21-9. [Persian]

15- Sepehri-Moghadam H, Rahbarian R, Sadoughi SD. The effect of aqueous extract of Launaea acanthodes (Boiss.) 0. Kuntze on the serum level of insulin and blood glucose and histomorphological changes of pancreas in diabetic rats. Feyz. 2015;19(1):30-7. [Persian]

16- Jalali M, Behnam Rassouli M, Tehranipour M, Ghayour N, Khayatzadeh J, Jannati H. Study of the effects of hyperglycemia and Launaea acanthodes extract administration on disorders of liver function in rats. Physiol Pharmacol. 2012;15(4):562-71. [Persian] 